\title{
Diagnosa Dini Penyakit Mata Menerapkan Metode Case Based Reasoning (CBR)
}

\author{
Dwi Yuli Prasetyo ${ }^{1}$, Bayu Rianto ${ }^{1, *}$, Muhammad Sandi Rais ${ }^{2}$, Nurita Suwanti ${ }^{1}$ \\ ${ }^{1}$ Fakultas Teknik dan Ilmu Komputer, Prodi Sistem Informasi, Universitas Islam Indragiri, Riau, Indonesia \\ ${ }^{2}$ Program Studi Teknik Informatika, STIKOM Muhammadiyah Batam, Batam, Indonesia \\ Email: ${ }^{1}$ dwiyuliprasetyo@gmail.com, ${ }^{2,}{ }^{*}$ rianto.bayu91@gmail.com, ${ }^{3}$ mhdsandirais@ gmail.com, ${ }^{4}$ nurrita@gmail.com \\ Email Penulis Korespondensi: rianto.bayu91@gmail.com
}

\begin{abstract}
Abstrak-Mata merupakan alat indra yang terdapat pada manusia. Mata mempunyai kemampuan menyesuaikan jumlah cahaya yang masuk, memusatkan perhatian pada objek yang dekat dan jauh serta menghasilkan gambaran yang berkesinambungan dan dihantarkan ke otak. Gangguan-gangguan yang menyebabkan kerusakan pada mata, dapat terjadi kerusakan akibat mata kelelahan, kurang tidur, terkena debu, terlalu lama di depan komputer dan sebagainya. Penelitian ini bertujuan untuk menganalisis dan merancang sistem pakar diagnosa dini penyakit pada mata yang mencakup informasi penyakit, baik gejala maupun solusinya, dan berperan untuk menggantikan dan menirukan proses penalaran dari seorang pakar dalam memecahkan masalah spesifikasi. Metode yang digunakan untuk penalaran adalah case base reasoning (CBR) dan Hasil dari penelitian adalah sistem pakar diagnose dini penyakit mata yang terkomputerisasi yang dapat digunakan untuk memberikan informasi yang berguna dalam pendiagnosaan penyakit.
\end{abstract}

Kata Kunci: Sistem Pakar; Analisis Pengetahuan; Rule; Case Base Reasoning

\begin{abstract}
The eye is a sense organ found in humans. The eye has the ability to adjust the amount of light that enters, focus attention on objects near and far and produce a continuous image and is conveyed to the brain. Distractions that cause damage to the eyes, can occur due to eye fatigue, lack of sleep, exposure to dust, too long in front of the computer and so on. This study aims to analyze and design an expert system for early diagnosis of diseases of the eye that includes disease information, both symptoms and solutions, and plays a role in replacing and mimicking the reasoning process of an expert in solving specification problems. The method used for reasoning is case base reasoning (CBR) and the results of the study are an expert system for early diagnosis of computerized eye diseases that can be used to provide useful information in diagnosing disease.
\end{abstract}

Keywords: Expert System; Knowledge Analysis; Rule; Case Base Reasoning

\section{PENDAHULUAN}

Dengan adanya kemajuan dan perkembangan teknologi yang semakin pesat, dikembangkan suatu teknologi yang mampu memproses dan cara berpikir manusia dengan teknologi kecerdasan buatan[1], yaitu dengan sistem pakar yang merupakan salah satu bagian dari kecerdasan buatan yang mengandung pengetahuan dan pengalaman yang dimasukkan oleh satu atau banyak pakar ke dalam satu area untuk membantu masyarakat dalam mendapatkan informasi mengenai penyakit mata dan memberikan solusi untuk menangani penyakit tersebut, sehingga diperlukan perangkat lunak untuk membantu mendeteksi penyakit mata secara dini sebelum berkonsultasi lebih lanjut dengan dokter mata.

Sistem pakar merupakan perangkat lunak yang didesain khusus berdasarkan Artificial Intelegence, berfungsi untuk merekam dan menduplikasikan kemampuan pakar. Dengan menggunakan sistem pakar, pemakai akan diajukan beberapa pertanyaan, dan pemakai harus memasukkan jawaban atau memilih jawaban yang ditampilkan di layar komputer sehingga pemakai dapat menemukan rekomendaasi yang harus ditempuh pemakai berdasarkan jawaban yang dipilihnya. Sistem pakar tersebut telah melacak solusi atau kesimpulan yang akan ditempuh oleh pemakainya. Pada saat ini sistem pakar sangat berguna untuk memecahkan masalah yang rumit, mengambil keputusan bahkan berguna untuk mendiagnosa penyakit[2].

Mata merupakan alat indra yang terdapat pada manusia. Mata mempunyai kemampuan menyesuaikan jumlah cahaya yang masuk, memusatkan perhatian pada objek yang dekat dan jauh serta menghasilkan gambaran yang berkesinambungan dan dihantarkan ke otak. Gangguan-gangguan yang menyebabkan kerusakan pada mata, dapat terjadi kerusakan akibat mata kelelahan, kurang tidur, terkena debu, terlalu lama di depan komputer dan sebagainya[3].

Dari permasalahan diatas maka dapat di bangun rekayasa perangkat lunak dengan metode case based reasoning untuk mendiagnosa penyakit pada mata dengan menggunakan aplikasi berbasis web. PHP singkatan dari hypertext preprocessor yang merupakan server side programming,yaitu bahasa pemrograman yang diproses di sisi server. Fungsi utama PHP dalam membagun website adalah untuk melakukan pengolahan datapada database. Data website akan dimasukan kedatabase, diedit, dihapus, dan ditampilkan padawebsite yang diatur oleh PHP[4].

Dalam proses mendiagnosa untuk mendapatkan suatu solusi, maka penulis mewawancarai beberapa pasien yang mengalami gangguan pada mata dengan sebuah penelitia dengan judul " Diagnosa Dini Penyakit Mata Metode Case Based Reasoning (CBR) ". Secara keseluruhan aplikasi telah sesuai dengan kebutuhan perusahaan maupun masyarakat. Masyarakat merasakan kemudahan dan keamanan dalam proses pemeriksaan [5]. 


\section{METODOLOGI PENELITIAN}

Penelitian ini bertujuan untuk mengembangkan sebuah system pakar untuk diagnose dini penyakit mata dengan menggunaka metode Case Base Reasoning (CBR), untuk mencapai tujuan tersebut maka langkah-langkah yang dilakukan adalah sebagai berikut:

\subsection{Kajian Pustaka}

Dalam sebuah buku yang ditulis oleh sutojo tahun 2016 mengungkapkan system pakar merupakan cabang dari Artificial Intelligence (AI) yang cukup tua karena sistem ini mulai dikembangkan pada pertengahan 1960. Sistem pakar yang muncul pertama kali adalah General-purpose problem solver (GPS) yang dikembangkan oleh Newel dan Simon. Istilah sistem pakar berasal dari istilah Knowledge-based expert system [6]. Pengembangan sebuah system pakar dapat ditunjang dengan penggunaan sebuah metode dalam penelitian ini menggunakan metode Case Base Reasoning (CBR) dimana menurut emha, 2018 mendeklarasikan CBR adalah salah satu metode untuk membangun sistem pakar dengan pengambilan keputusan dari kasus yang baru dengan berdasarkan solusi dari kasus - kasus sebelumnya. Secara umumnya terdapat empat langkah proses pada metode Case Based Reasoning, yaitu Retrieve (memperoleh kembali) kasus atau kasus-kasus yang paling mirip, Reuse (menggunakan) informasi dan pengetahuan dari kasus tersebut untuk memecahkan permasalahan, Revise (meninjau kembali/memperbaiki) usulan solusi, dan Retain (menyimpan) bagian-bagian dari pengalaman tersebut yang mungkin berguna untuk memecahkan masalah di masa yang akan datang [7]. Dimana penelitian ini juga akan mengkombinasikan sistem yang terkomputerisasi dengan sebuah sistem yang berbasis web dengan harapan dapat menyentuh dan mempermudah semua lapisan masyarakat, dapat dirujuk Komputer adalah seperangkat atau sekelompok mesin elektronik yang terdiri dari ribuan bahkan jutaan yang saling bekerja sama, serta membentuk sebuah sistem kerja yang rapi dan teliti [8]. Website adalah suatu media publikasi elektronik yang terdiri dari halaman-halaman web (web page) yang terhubung satu dengan yang lain menggunakan Linkyang dilekatkan pada suatu teks atau image.Website dibuat pertama kali oleh Tim Barners Lee pada tahun 1990. Website dibangun dengan menggunakan bahasa Hypertext Markup Language(HTML) dan memanfaatkan protokol komunikasi Hypertext Transfer Protocol(HTTP) yang terletak padaapplication layerpada referensi layerOSI. Halaman website diakses menggunakan aplikasi yang disebut internet browser (Kadir, 2004). Menurut (Jasmadi,2004) [9], fungsi dari website adalah :Fungsi Komunikasi, Fungsi Informasi, Fungsi Hiburan, Fungsi Transaksi dan Fungsi Pendidikan. Selain itu referensi lain PHP singkatan dari hypertext preprocessor yang merupakan server side programming, yaitu bahasa pemrograman yang diproses di sisi server. Fungsi utama PHP dalam membagun website adalah untuk melakukan pengolahan datapada database. Data website akan dimasukan kedatabase, diedit, dihapus, dan ditampilkan padawebsite yang diatur oleh PHP [10] [11]. Selain penggunaan metode penggunaan alat bantu seperti UML juga digunakan dalam pemodelan pada penelitian diagnose dini penyakit mata ini dimana UML singkatan dari Unifed Modeling Leangue yang berarti bahasa pemodelan standar [12].

\subsection{Analisa Penyakit Mata}

Untuk mendiagnosa suatu penyakit perlu diketahui terlebih dahulu gejala gejala yang ditimbulkan. Meskipun hanya gejala klinis (gejala-gejala yang terlihat langsung maupun yang dirasakan oleh penderita), dokter dapat mengambil suatu kesimpulan berupa penyakit yang diderita. Tetapi ada kalanya pemeriksaan lebih lanjut melalui pemeriksaan laboraturium untuk penyakit tertentu. Ada banyak penyebab penyakit mata, selain karena gizi yang tidak tepat, polusi, Menonton televisi pada jarak yang sangat dekat, atau Berhadapan dengan monitor komputer terus menerus, penyakit mata juga bisa disebabkan kurang nya asupan gizi terutama kurang nya vitamin A [13]. Berikut macam-macam penyakit mata seperti pada Tabel 1 meliputi:

Tabel 1. Data Macam-Macam Penyakit Mata

\begin{tabular}{cll}
\hline No & \multicolumn{1}{c}{ Kode Penyakit } & \multicolumn{1}{c}{ Nama Penyakit } \\
\hline 1 & KP1 & Aldasio \\
2 & KP2 & Dakriosistitis \\
3 & KP3 & Glaukoma \\
4 & KP4 & Katarak \\
5 & KP5 & Konjungtivitas (menular) \\
6 & KP6 & Xerophtalmia (rabun senja) \\
7 & KP7 & Xerosis (mata kering) \\
8 & KP8 & Miopi (rabun jauh) \\
9 & KP9 & Presbiopi (rabun dekat menular) \\
10 & KP10 & Buta Warna \\
11 & KP11 & Trakoma (menular) \\
12 & KP12 & Selulitis Orbitalis \\
13 & KP13 & Blefaritis \\
14 & KP14 & Dakrosistitis \\
\hline
\end{tabular}


JURNAL MEDIA INFORMATIKA BUDIDARMA

Volume 5, Nomor 2, April 2021, Page 360-369

ISSN 2614-5278 (media cetak), ISSN 2548-8368 (media online)

Available Online at https://ejurnal.stmik-budidarma.ac.id/index.php/mib

DOI 10.30865/mib.v5i2.2779

\begin{tabular}{cll}
\hline No & \multicolumn{1}{c}{ Kode Penyakit } & \multicolumn{1}{c}{ Nama Penyakit } \\
\hline 15 & KP15 & Ulkus Kornea \\
16 & KP16 & Degenerasi Makula \\
17 & KP17 & Endoftalmitis \\
\hline
\end{tabular}

\subsection{Tahap Akuisisi Pengetahuan}

Tahap ini merupakan kegiatan pengumpulan pengetahuan dari sumber-sumber seperti pakar, buku, jurnal dan dari berbagai sumber. Pengetahuan yang dikumpulkan berkaitan dengan penelusuran macam-macam penyakit mata dengan mengamati gejala-gejala yang timbul pada mata [14].

Data-data dari berbagai sumber pengetahuan harus diolah sedemikian rupa sehingga menghasilkan solusi yang baik. Berikut adalah data gejala-gejala penyakit mata dapat dilihat pada sebagai berikut [14] [15]

1. Ablasio

2. Dakriosistitis

3. Glaukoma

4. Katarak

5. Konjungtivitis

6. Xerophtalmia

7. Xorosis

8. Miopi

9. Presbiopi

10. Buta Warna

11. Trakoma

12. Sebrulitis Obritalis

13. Blefaritis

14. Dakrosistitits

15. Ulkus Kornea

16. Degenerasi Makula

17. Endoftalmitis

\subsection{Pembentukan Aturan (Rule)}

Dengan pembentukan aturan (rule) maka dapat dengan mudah mengetahui hasil akhir berikut adalah tabel 2. pembentukan rule :

Tabel 2. Contoh Pembentukan Rule

\begin{tabular}{|c|c|c|c|c|}
\hline No & $\begin{array}{c}\text { Kode } \\
\text { Gejala }\end{array}$ & Gejala Penyakit & $\begin{array}{c}\text { Nama } \\
\text { Penyakit }\end{array}$ & Pengobatan \\
\hline 1 & $\begin{array}{l}\text { GA1 } \\
\text { GA2 } \\
\text { GA3 } \\
\text { GA4 }\end{array}$ & $\begin{array}{l}\text { Terlihat benda melayang-layang } \\
\text { Kilatan cahaya } \\
\text { Penurunan tajam penglihatan } \\
\text { Ada semacam tirai tipis semacam } \\
\text { parabola yang naik perlahan-lahan dari } \\
\text { mulai bagian bawah bola mata dan } \\
\text { akhirnya menutup. }\end{array}$ & Aldasio & $\begin{array}{l}\text { Hindari caha yang } \\
\text { berlebihan }\end{array}$ \\
\hline 2 & $\begin{array}{l}\text { GD1 } \\
\text { GD2 } \\
\text { GD3 }\end{array}$ & $\begin{array}{l}\text { Nyeri } \\
\text { Kemerahan pembengkakan pada keopak } \\
\text { mata bawah } \\
\text { Terjadinya pengeluaran air mata } \\
\text { berlebihan (epiro) }\end{array}$ & Dakriosistitis & $\begin{array}{l}\text { Pemberian antiobotika oral } \\
\text { atau melalui pembuluh } \\
\text { darah. } \\
\text { dengan air hangan disekitar } \\
\text { kantung air mata. }\end{array}$ \\
\hline 3 & $\begin{array}{l}\text { GG1 } \\
\text { GG2 } \\
\text { GG3 }\end{array}$ & $\begin{array}{l}\text { Bila memandang lampu maka akan timbul } \\
\text { warna pelangi } \\
\text { Mata terasa sakit karena posisi mata } \\
\text { dalam keadaan bengkak } \\
\text { Rasa ingin mengedip terus menerus } \\
\text { dengan menekan kedipan berlebihan }\end{array}$ & Glaukoma & $\begin{array}{l}\text { Mengkonsumsi } r \text { kulit } \\
\text { manggis karena memiliki } \\
\text { khasiat kandungan sebagai } \\
\text { penyembuh. }\end{array}$ \\
\hline 4 & $\begin{array}{l}\text { GK1 } \\
\text { GK2 } \\
\text { GK3 } \\
\text { GK4 } \\
\text { GK5 }\end{array}$ & $\begin{array}{l}\text { Penglihatan Buram } \\
\text { Ketajaman penglihatan berkurang } \\
\text { Sensitivitas } \\
\text { Kontras } \\
\text { Bayangan dan visi kurang jelas }\end{array}$ & Katarak & $\begin{array}{l}\text { Dapat disembuhkan dengan } \\
\text { cara pengobatan alternative } \\
\text { dan melakukan operasi.. }\end{array}$ \\
\hline
\end{tabular}




\subsection{Analisis Basis Pengetahuan}

Yang menjadi basis pengetahuan pada case-based reasoning adalah fakta berupa kaus-kasus sebelumnya yang pernah ada dan serangkaian alur untuk memeriksa, menghitung, serta menyimpulkan suatu dari permasalahan yang diberikan. Tahapan pada case-based reasoning ada 3 yaitu: retrieve, reuse, dan revise [15].

Pencarian solusi kasus di lakukan pada tahapan retrieve dan reuse. Tahapan retrieve melakukan pencarian tingkat kemiripan kasus inputan pertanyaan gejala-gejala yang diberikan pasien dengan kasus-kasus yang ada pada knowledge base untuk mencari kasus yang memiliki persamaan (similaritas) tertinggi [16].

$$
\text { Similarity }(\mathrm{T}, \mathrm{S})=\frac{\left(\mathrm{S}_{1} * \mathrm{~W}_{1}\right)+\left(\mathrm{S}_{2} * \mathrm{~W}_{2}\right)+\ldots \ldots+\left(\mathrm{S}_{\mathrm{n}} * \mathrm{~W}_{\mathrm{n}}\right)}{\mathrm{W}_{1}+\mathrm{W}_{2}+\ldots \ldots+\mathrm{Wn}}
$$

\section{HASIL DAN PEMBAHASAN}

Dalam penelitian ini hasil dan pemabahan terkait dengan bagaimana pengujian dilaksanakan untuk mengetahui sejauh mana sistem yang dikembangkan ini dapat menganalisis secara dini penyakit mata. Pengujian dilakukan beberapa tahapan, yang meliputi pembuatan rule atau basis pengetahuan sampai dengan penggunaan Case Base Reasoning (CBR) untuk mendeklarasikan gejala penyakit mata berdasarkan klasifikasi yang ada.

\subsection{Pembentukan aturan}

Dengan pembentukan aturan (rule) maka dapat dengan mudah mengetahui hasil akhir berikut adalah tabel 3 pembentukan rule :

Tabel 3. Pembentukan Rule (Aturan)

\begin{tabular}{|c|c|c|c|c|}
\hline No & $\begin{array}{c}\text { Kode } \\
\text { Gejala }\end{array}$ & Gejala Penyakit & $\begin{array}{c}\text { Nama } \\
\text { Penyakit } \\
\end{array}$ & Pengobatan \\
\hline 1 & $\begin{array}{l}\text { GA1 } \\
\text { GA2 } \\
\text { GA3 } \\
\text { GA4 }\end{array}$ & $\begin{array}{l}\text { Terlihat benda melayang-layang } \\
\text { Kilatan cahaya } \\
\text { Penurunan tajam penglihatan } \\
\text { Ada semacam tirai tipis semacam parabola } \\
\text { yang naik perlahan-lahan dari mulai bagian } \\
\text { bawah bola mata dan akhirnya menutup. }\end{array}$ & Aldasio & $\begin{array}{lll}\text { Hindari caha yang } \\
\text { berlebihan }\end{array}$ \\
\hline 2 & $\begin{array}{l}\text { GD1 } \\
\text { GD2 } \\
\text { GD3 }\end{array}$ & $\begin{array}{l}\text { Nyeri } \\
\text { Kemerahan pembengkakan pada keopak mata } \\
\text { bawah } \\
\text { Terjadinya pengeluaran air mata berlebihan } \\
\text { (epiro) }\end{array}$ & Dakriosistitis & $\begin{array}{l}\text { Pemberian antiobotika oral } \\
\text { atau melalui pembuluh } \\
\text { darah. Pengompresan } \\
\text { dengan air hangan disekitar } \\
\text { kantung air mata. }\end{array}$ \\
\hline 3 & $\begin{array}{l}\text { GG1 } \\
\text { GG2 }\end{array}$ & $\begin{array}{l}\text { Bila memandang lampu maka akan timbul } \\
\text { warna pelangi } \\
\text { Mata terasa sakit karena posisi mata dalam } \\
\text { keadaan bengkak } \\
\text { Rasa ingin mengedip terus menerus dengan } \\
\text { menekan kedipan berlebihan }\end{array}$ & Glaukoma & $\begin{array}{l}\text { Mengkonsumsi kulit } \\
\text { manggis karena memiliki } \\
\text { khasiat kandungan sebagai } \\
\text { penyembuh. }\end{array}$ \\
\hline 4 & $\begin{array}{l}\text { GK1 } \\
\text { GK2 } \\
\text { GK3 } \\
\text { GK4 } \\
\text { GK5 }\end{array}$ & $\begin{array}{l}\text { Penglihatan Buram } \\
\text { Ketajaman penglihatan berkurang } \\
\text { Sensitivitas } \\
\text { Kontras } \\
\text { Bayangan dan visi kurang jelas }\end{array}$ & Katarak & $\begin{array}{l}\text { Dapat disembuhkan dengan } \\
\text { cara pengobatan alternative } \\
\text { dan melakukan operasi.. }\end{array}$ \\
\hline 5 & $\begin{array}{l}\text { GKJ1 } \\
\text { GKJ2 } \\
\text { GKJ3 } \\
\text { GKJ4 } \\
\text { GKJ5 } \\
\text { GKJ6 } \\
\text { GKJ7 } \\
\text { GKJ8 } \\
\text { GKJ9 } \\
\text { GKJ10 } \\
\text { GKJ11 }\end{array}$ & $\begin{array}{l}\text { Iritasi } \\
\text { Infeksi } \\
\text { Virus } \\
\text { Alergi debu } \\
\text { Bulu mata sering jatuh } \\
\text { Sering menggunakan kontak lensa } \\
\text { Jarang membersihkan mata } \\
\text { Mata terasa nyeri } \\
\text { Pandangan kabur } \\
\text { Peka terhadap cahaya } \\
\text { Terbentuk teropong pada kelopak mata pada } \\
\text { saat bangun tidur }\end{array}$ & Konjungtivitas & $\begin{array}{l}\text { Kompres mata dengan air } \\
\text { hangat atau gunnakan obat } \\
\text { tetes mata, salap antibiotic } \\
\text { sesuai resep dokter. }\end{array}$ \\
\hline 6 & GXP1 & Rabun senja & Xerophtalmia & Sering-sering \\
\hline
\end{tabular}


JURNAL MEDIA INFORMATIKA BUDIDARMA

Volume 5, Nomor 2, April 2021, Page 360-369

ISSN 2614-5278 (media cetak), ISSN 2548-8368 (media online)

Available Online at https://ejurnal.stmik-budidarma.ac.id/index.php/mib DOI 10.30865/mib.v5i2.2779

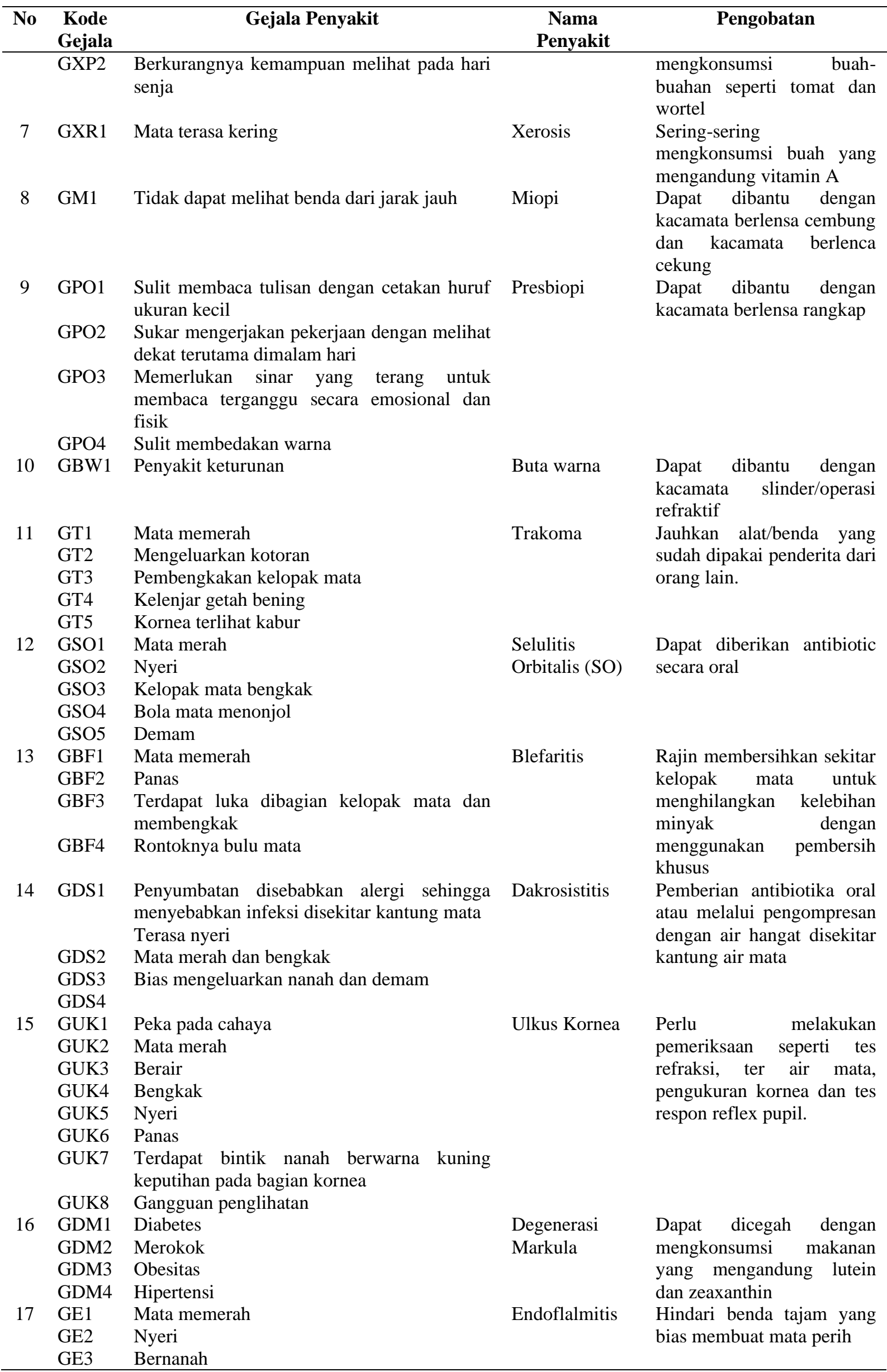


ISSN 2614-5278 (media cetak), ISSN 2548-8368 (media online)

Available Online at https://ejurnal.stmik-budidarma.ac.id/index.php/mib DOI 10.30865/mib.v5i2.2779

\begin{tabular}{ccccc}
\hline No & $\begin{array}{c}\text { Kode } \\
\text { Gejala }\end{array}$ & \multicolumn{1}{c}{ Gejala Penyakit } & $\begin{array}{c}\text { Nama } \\
\text { Penyakit }\end{array}$ & Pengobatan \\
\hline GE4 & $\begin{array}{l}\text { Tertusuk sesuatu seperti lidi yang membuat } \\
\text { mata kelilipan }\end{array}$ & \\
\hline
\end{tabular}

\subsection{Analisis Basis Pengetahuan dengan CBR}

Yang menjadi basis pengetahuan pada case-based reasoning adalah fakta berupa kaus-kasus sebelumnya yang pernah ada dan serangkaian alur untuk memeriksa, menghitung, serta menyimpulkan suatu dari permasalahan yang diberikan. Tahapan pada case-based reasoning ada 3 yaitu: retrieve, reuse, dan revise.

Berikut adalah tabel 4 gejala penyakit untuk mementukan hasil nilai bobot :

Tabel 4. Data Gejala Penyakit Mata (Katarak)

\begin{tabular}{cclc}
\hline No & Kode Gejala & \multicolumn{1}{c}{ Gejala Penyakit } & Bobot \\
\hline 1 & GK1 & Penglihatan buram & 0,3 \\
2 & GK2 & Ketajaman penglihatan berkurang & 0,3 \\
3 & GK3 & Sensitivitas & 1 \\
4 & GK4 & Kontras & 1 \\
5 & GK5 & Bayangan dan visi kurang jelas & 0,3 \\
\hline
\end{tabular}

Tabel 5. Data Gejala Penyakit Mata (Konjungtivitas)

\begin{tabular}{cclc}
\hline No & Kode Gejala & \multicolumn{1}{c}{ Gejala Penyakit } & Bobot \\
\hline 1 & GKJ1 & Iritasi & 0,3 \\
2 & GKJ2 & Infeksi & 0,3 \\
3 & GKJ3 & Virus & 0,3 \\
4 & GKJ4 & Alergi debu & 0,3 \\
5 & GKJ5 & Bulu mata sering jatuh & 1 \\
6 & GKJ6 & Sering menggunakan lensa kontak & 1 \\
7 & GKJ7 & Jarang membersihkan mata & 0,3 \\
8 & GKJ8 & Pandangan kabur & 0,3 \\
9 & GKJ9 & Mata terasa nyeri & 0,3 \\
10 & GKJ10 & Peka terhadap cahaya & 0,3 \\
11 & GKJ11 & Terbentuk topeng pada kelopak mata saat bangun tidur & 0,3 \\
\hline
\end{tabular}

Tabel 6. Data Gejala Penyakit Mata (Presbiopi)

\begin{tabular}{cclc}
\hline No & Kode Gejala & \multicolumn{1}{c}{ Gejala Penyakit } & Bobot \\
\hline 1 & GUK1 & Peka pada cahaya & 0,3 \\
2 & GUK2 & Mata merah & 0,3 \\
3 & GUK3 & Berair & 0,3 \\
4 & GUK4 & Bengkak & 0,3 \\
5 & GUK5 & Nyeri & 0,3 \\
6 & GUK6 & Panas & 1 \\
7 & GUK7 & Terdapat bitik nanah berwarna kuning keputihan pada & 1 \\
& & bagian kornea & 0,3 \\
\hline
\end{tabular}

\subsection{Retrival (Penelusuran)}

Retrieval yang digunakan dalam penelitian ini adalah menelusuri kembali kasus (gejala klinis) lama yang paling menyerupai/relevan dengan kasus baru. Pencocokan dilakukan dengan cara memilih gejala-gejala dengan memberi tanda checkbox terhadap pertanyaan gejala yang sesuai dengan kondisi pasien. Jika pencocokan nilai jawaban kasus sama atau hampir sama dengan basis kasus, maka akan dilakukan tahap reuse yaitu melakukan perhitungan similarity yang menghasilkan kemungkinan jenis penyakit dan akan disarankan solusi obat untuk menjadi solusi dari kasus baru. Asumsi pada penelusuran ini adalah kasus yang mirip akan memiliki solusi yang mirip. Data pertanyaan gejala klinis yang dimasukan pada sistem berbentuk biner (1) atau $(0,3)$. Dari tanda checkbox untuk menyatakan "ya" (1) bahwa ada gejala dan tidak memberi tanda checkbox menyatakan "tidak" $(0,3)$ bahwa tidak ada gejala. Setiap nilai gejala similar akan dikalikan oleh bobot. Nilai $=$ [nilai checkbox dipilih 1 atau tidak $0,3(\mathrm{~S})] *$ bobot $(\mathrm{W})$. Penelusuranan pada aplikasi ini menggunakan teknik Similarity (problem,case) pada algoritma k-nearest neighbor sebagai berikut : Bobot parameter $(\mathrm{w})$ :

Gejala Penting $=1$

Gejala Biasa $=0,3$

Similarity $(\mathrm{T}, \mathrm{S})=\frac{s_{1} * w_{1}+w_{2}+\ldots \ldots+s_{n} * w_{n}}{w_{1}+w_{2}+\ldots \ldots+w_{n}}$ 


\section{JURNAL MEDIA INFORMATIKA BUDIDARMA}

Volume 5, Nomor 2, April 2021, Page 360-369

ISSN 2614-5278 (media cetak), ISSN 2548-8368 (media online)

Available Online at https://ejurnal.stmik-budidarma.ac.id/index.php/mib

DOI 10.30865/mib.v5i2.2779

\section{Keterangan:}

$\mathrm{S}=$ similarity (nilai kemiripan) yaitu 0,3 (sama) dan 1 (beda)

$\mathrm{W}=$ weight (bobot yang diberikan).

Berikut ini contoh analisis pengambilan kesimpulan status hasil diagnosa dengan proses pencarian Similarity. Dari hasil inputan gejala-gejala kasus baru diperoleh 3 kasus yang mempunyai kemiripan dengan kasus lama yaitu kasus K001, K002, K003. Seperti terlihat pada Tabel 7 dibawah ini.

Tabel 7. Kasus Lama

\begin{tabular}{|c|c|c|c|c|}
\hline \multicolumn{5}{|c|}{ Kasus Lama } \\
\hline \multirow[t]{2}{*}{ Kode Gejala } & \multirow[t]{2}{*}{ Gejala } & \multicolumn{3}{|c|}{ Basis Lama } \\
\hline & & K001 & K002 & K003 \\
\hline GK3 & Penglihatan buram & 1 & - & - \\
\hline GKJ8 & Nyeri & - & 0,3 & 0,3 \\
\hline GUK6 & Panas & - & - & 3 \\
\hline GUK8 & Gangguan penglihatan & 0,3 & - & 0,3 \\
\hline \multicolumn{2}{|c|}{ Gejala sama yang terdeteksi } & 2 & 1 & 3 \\
\hline \multicolumn{5}{|c|}{ Tabel 8. Kasus Baru } \\
\hline \multicolumn{5}{|c|}{ Kasus Baru } \\
\hline \multirow[t]{2}{*}{ Kode Gejala } & \multirow[t]{2}{*}{ Gejala } & \multicolumn{3}{|c|}{ Basis Lama } \\
\hline & & K001 & K002 & K003 \\
\hline GK3 & Penglihatan buram & 1 & - & - \\
\hline GK4 & Kontras & 0,3 & - & - \\
\hline GKJ5 & Bulu mata sering jatuh & - & 1 & - \\
\hline GKJ8 & Nyeri & - & 0,3 & 0,3 \\
\hline GUK6 & Panas & - & - & 1 \\
\hline \multirow[t]{2}{*}{ GUK8 } & Gangguan penglihatan & 0,3 & - & 0,3 \\
\hline & la sama yang terdeteksi & 3 & 2 & 3 \\
\hline
\end{tabular}

Berdasarkan tabel diatas perlu dihitung Similarity kasus lama terhadap kasus baru. Ada 3 kasus yang terdeteksi mirip dengan kasus baru, dengan jumlah kemiripan atau gejala yaitu (1) K001 = 3 gejala; (2) K002 = 2 gejala; (3) K003 = 3 gejala.

1. Similarity (sama gejalanya) terhadap jenis penyakit mata yang diderita pasien K001 yaitu gejala yang terdeteksi $=(\mathrm{GK} 3, \mathrm{GUK} 8)$

$$
\begin{aligned}
& =\frac{[(1 * 0,3)+(0 * 0,3)+(1 * 1)+(1 * 1)+(0 * 0,3)]}{0,3+0,3+1+1+0,3} \\
& =\frac{0,3+0+1+1+0}{2,9} \\
& =2,3 / 2,9 \\
& =0,793
\end{aligned}
$$

2. Similarity (sama gejalanya) terhadap jenis penyakit mata ya)ng diderita pasien K002 yaitu gejala yang terdeteksi $=(\mathrm{GKJ} 5)$

$$
\begin{aligned}
& =\frac{(1 * 0,3)+(0 * 0,3)+(0 * 0,3)+(0 * 0,3)+(1 * 1)+(1 * 1)+(0 * 0,3)+(0 * 0,3)+(0 * 0,3)+(1 * 1)+(0 * 0,3)}{0,3+0,3+0,3+0,3+1+1+0,3+0,3+0,3+1+0,3} \\
& =\frac{0,3+0+0+0+1+1+0+0+0+1+0}{5,1} \\
& =3,3 / 5,1 \\
& =0,647
\end{aligned}
$$

3. Similarity (sama gejalanya) terhadap jenis penyakit mata yang diderita pasien K003 yaitu gejala yang terdeteksi $=($ GKJ8, GUK6, GUK 8)

$$
\begin{aligned}
& =\frac{[(1 * 0,3)+(0 * 0,3)+(0 * 0,3)+(0 * 0,3)+(0 * 0,3)+(1 * 1)+(1 * 1)+(0 * 0,3)]}{0,3+0,3+0,3+0,3+0,3+1+1+0,3} \\
& =\frac{0,3+0+0+0+0+1+1+0}{3,8} \\
& =2,3 / 3,8 \\
& =0,605
\end{aligned}
$$

Maka kesimpulannya adalah kasus dengan kode K003, tingkat kemiripannya sebesar 0,793 atau 79,3\% merupakan kasus terdekat dengan Similarity tertinggi terhadap kasus baru.

\subsection{Implementasi Program}

Berikut adalah implementasi program sesuai dengan rancangan pada perancangan sistem yang telah di rancang sebelum nya. 
JURNAL MEDIA INFORMATIKA BUDIDARMA

Volume 5, Nomor 2, April 2021, Page 360-369

ISSN 2614-5278 (media cetak), ISSN 2548-8368 (media online)

Available Online at https://ejurnal.stmik-budidarma.ac.id/index.php/mib DOI 10.30865/mib.v5i2.2779

\section{a. Menu Home}

Menu home merupakan tampila awal web dari sistem pakar diagnosa penyakit mata, pada tampilan awal ini terdepat beberapa sub menu yang diantaranya ialah home, petunjuk, konsultasi dan login serta menampilkan tanggal pembukaan web atau tanggal chek diagnosa, Gambar 2 berikut merupakan tampilan menu home:

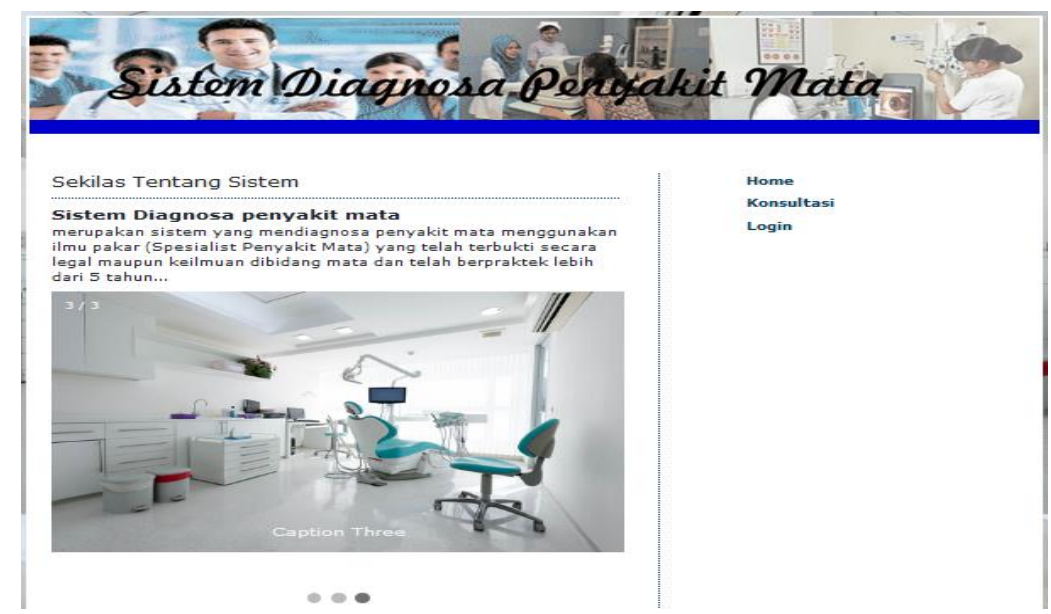

Gambar 2. Tampilan Menu Home

\section{b. Tampilan Menu Konsultasi}

Menu konsultasi merupaan tampilan untuk menyatakan keluhan penyakit mata yang diderita pasien kepada sistem pakar diagnosa penyakit mata, dimana pada menu konsultasi ini harus diisi data rupa diri registrasi pada menu konsultasi ini harus diisi data rupa diri registrasi sebelum konsultasi dilakukan, seperti gambar 3 dibawah ini.

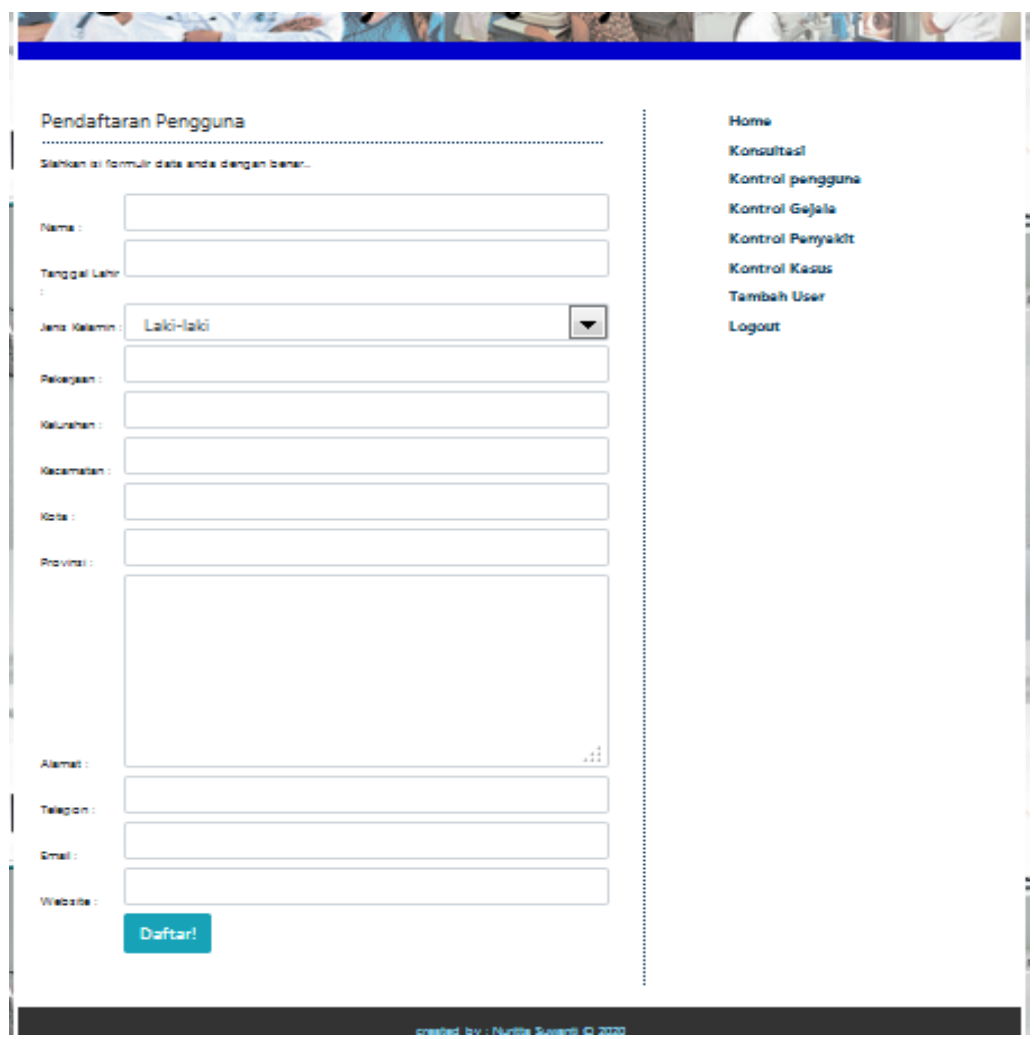

Gambar 3. Tampilan Menu Konsultasi

\section{c. Tampilan Menu Daftar Nama Penyakit}

Menu daftar Penyakit mata merupkan tampilan data tentang jenis penyakit mata yang ada pada sistem pakar diagnosa penyakit mata, diantaranya pada sistem ini terdapat jenis penyakit mata, solusi, keterangan, seperti gambar 4 dibawah ini. 


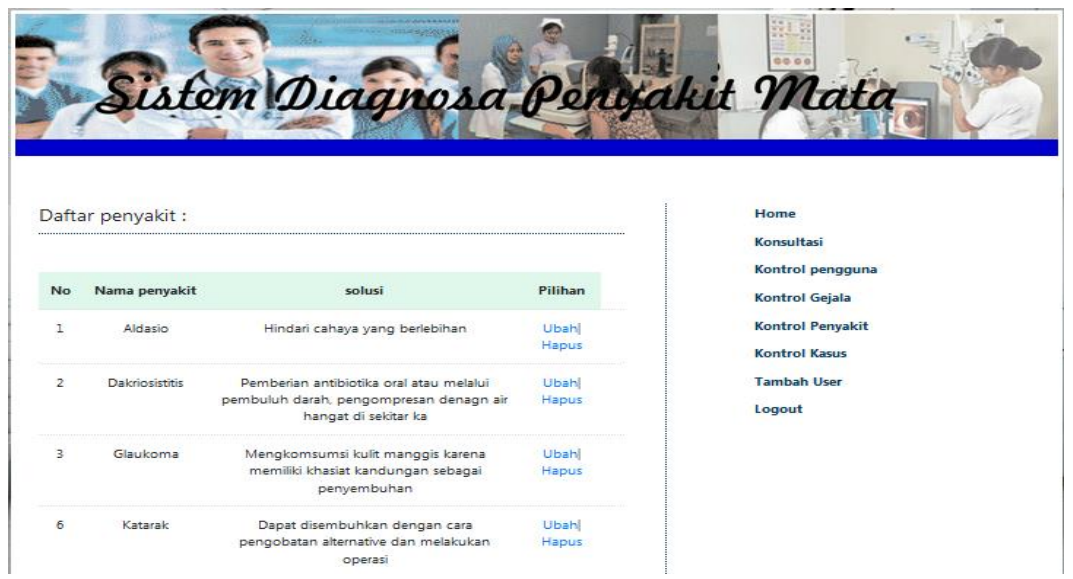

Gambar 4. Tampilan Menu Daftar Penyakit Mata

Pada Gambar 4 di atas merupakan tampilan menu daftar data penyakit mata, cara penggunaan nya yaitu, menu ini hanya di gunakan pada admin program untuk mengganti daftar penyakit, admin bisa mengklik ubah atau hapus jika ingin menambah data penyakit baru.

\section{d. Tampilan Hasil Diagnosa Penyakit Mata}

Menu laporan Diagnosa Penyakit mata merupakan tampilan hasil dari segala jenis penyakit mata yang telah diinputkan sebelumnya, hingga solusi mengatasinya, seperti gambar 5 dibawah ini.

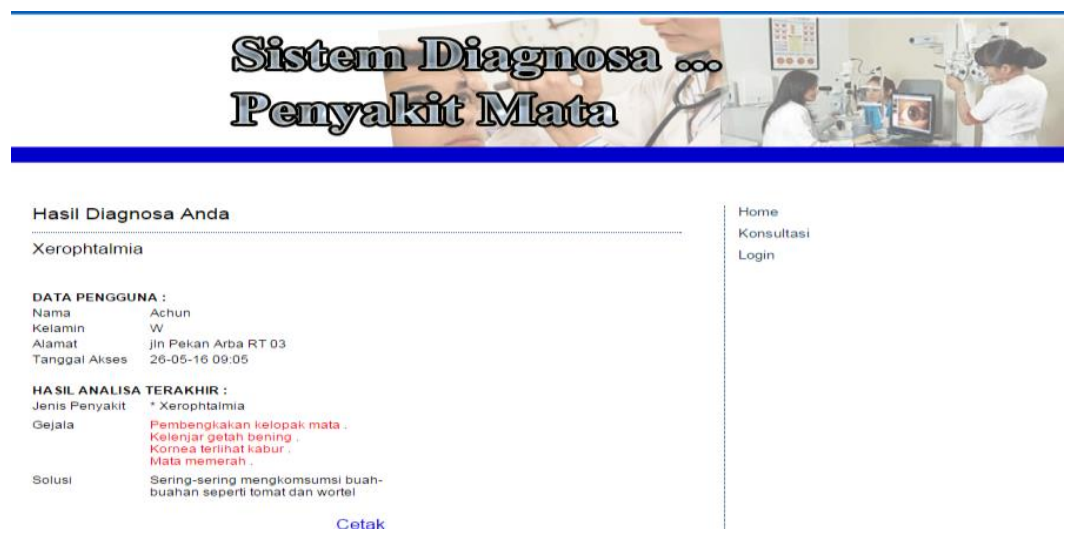

Gambar 5. Tampilan Hasil Diagnosa Penyakit Mata

\section{KESIMPULAN}

Berdasarkan hasil penelitian yang telah dilakukan dapat diambil kesimpulan bahwa Dengan adanya web sistem pakar Penyakit Mata ini, pengguna bisa langsung mengecek atau mendiagnosa dirinya sendiri dengan aplikasi web sistem pakar penyakit mata ini selain itu Database KnowLedge berhasil dibangun dan dengan adanya aplikasi sistem pakar penyakit mata ini, pasien mudah mengetahui jenis pentakit mata.

\section{UCAPAN TERIMAKASIH}

Terima kasih disampaikan kepada pihak-pihak yang telah mendukung terlaksananya penelitian ini.

\section{REFERENCES}

[1] B. Rianto, D. Irfan, N. Syah, and S. Anwar, "Information Technology Learning Applications," 2020.

[2] R. R. Permanawati and A. Yulianeu, "Sistem Pakar Untuk Menentukan Suatu Peluang Usaha Dengan Menggunakan Metode Smarter Dan Oreste," Jumantaka, vol. 1, no. 1, pp. 31-40, 2018.

[3] A. Mustofa, N. M. Ulfa, and M. Suryandari, "Profil Peresepan Penyakit Mata Glaukoma pada Pasien BPJS Rawat Jalan ( Studi dilaksanakan di RS Mata Masyarakat JawaTimur Periode Januari - Desember 2015 ),” vol. 1, no. 1, pp. 27-33, 2016.

[4] K. A. B. Inhil, "Website Penyediaan Informasi Rumah Kontrakan,” vol. 3, no. 2, 2019.

[5] Abdullah, B. Rianto, and S. Aina, "Prediksi Kualitas Ikan Senangin Berdasarkan Warna dan Tekstur," JIKO (Jurnal Inform. dan Komputer) STMIK AKAKOM, vol. 4, pp. 35-44, 2019. [6] “Kecerdasan
https://books.google.co.id/books?id=R7qgAQAACAAJ\&dq=kecerdasan+buatan+sutojo\&hl=id\&sa=X\&ved=2ahUKE 


\section{JURNAL MEDIA INFORMATIKA BUDIDARMA}

Volume 5, Nomor 2, April 2021, Page 360-369

ISSN 2614-5278 (media cetak), ISSN 2548-8368 (media online)

Available Online at https://ejurnal.stmik-budidarma.ac.id/index.php/mib

DOI 10.30865/mib.v5i2.2779

wjjqOmB_7XuAhVd63MBHeydBioQ6AEwAHoECAEQAQ (accessed Jan. 25, 2021).

[7] S. S. Pratiwi, T. Tursina, and H. S. Pratiwi, "Case Based Reasoning Diagnosis Gangguan Pencernaan pada Anak Menggunakan Metode Similarity Cosine Coefficient," J. Sist. dan Teknol. Inf., vol. 6, no. 4, p. 174, 2018, doi: 10.26418/justin.v6i4.27902.

[8] I. W. Fatmawati, S. Siswanti, and D. Nugroho, "Aplikasi E-Learning Sekolah Dasar (Sd) Muhammadiyah 2 Kauman Surakarta Untuk Menambah Interaksi Guru Dan Siswa,” J. TIKomSin, vol. Vol 3, No, p. 9, 2015, [Online]. Available: https://p3m.sinus.ac.id/jurnal/index.php/TIKomSiN/article/view/198.

[9] R. S. Teuku Fadjar Shadek, "Pengembangan Aplikasi Sistem E-Learning Pada Seluruh Mata Kuliah Dengan Menggunakan Program Hypertext Prepocessor ( Php ) Dalam Rangka Peningkatan Mutu Proses Dan Hasil Pembelajaran," J. ProTekInfo, vol. 4, pp. 1-18, 2017.

[10] I. P. Sari, "Implementasi Pembelajaran Berbasis E-Learning Menggunakan Claroline," Res. Dev. J. Educ., vol. 4, no. 1 , pp. 75-87, 2017, doi: 10.30998/rdje.v4i1.2070.

[11] J. F. Palandi, S. Aminah, and Z. E. Pudyastuti, "Pengembangan Aplikasi Web E-Learning Untuk Pendidikan Anti Korupsi Menggunakan Moodle," INOVTEK Polbeng - Seri Inform., vol. 2, no. 2, p. 173, 2017, doi: 10.35314/isi.v2i2.204.

[12] I. Zufria, "Pemodelan Berbasis UML ( Unified Modeling Language ) dengan Strategi Teknik Orientasi Objek User Centered Design ( UCD ) dalam Sistem Administrasi Pendidikan Pemodelan Berbasis UML ( Unified Modeling Language ) dengan," Pemodelan Berbas. UML (Unified Model. Lang. dengan Strateg. Tek. Orientasi Objek User Centered Des. dalam Sist. Adm. Pendidik., no. August, 2016.

[13] H. I. Pencahayaan, K. M. Dan, G. Ketajaman, P. Pada, and P. Bagian, "Hubungan Intensitas Pencahayaan, Kelelahan Mata Dan Gangguan Ketajaman Penglihatan Pada Pekerja Bagian Inspecting Pt. Tekstil X," J. Kesehat. Masy., vol. 7 , no. 4, pp. 67-73, 2019.

[14] J. Lanctot and F. Poulin, "Emerging Adulthood Features and Adjustment: A Person-Centered Approach," Emerg. Adulthood, vol. 6, no. 2, pp. 91-103, 2018, doi: 10.1177/2167696817706024.

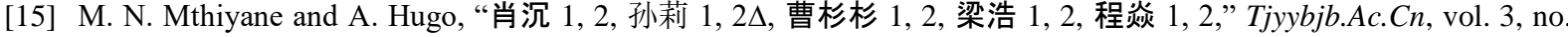
2252, pp. 58-66, 2019, [Online]. Available: http://www.tjyybjb.ac.cn/CN/article/downloadArticleFile.do?attachType=PDF\&id=9987. 